\title{
AZ ORGANIKUSCÍMKE-HATÁS A MARKETING IRODALOMBAN: IMÁZSTRANSZFER, HALO-HATÁS ÉS JELZÉS
}

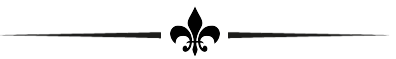

\section{THE ORGANIC LABEL EFFECT IN MARKETING LITERATURE: IMAGE TRANSFER, HALO EFFECT AND SIGNALING} \\ ${ }^{1}$ KISS, Marietta \\ ${ }^{1}$ KONTOR, Enikö \\ ${ }^{2}$ KuN, András Istuán \\ \&a \\ ${ }^{1}$ Debreceni Egyetem, Gazdaságtudományi Kar, Marketing és Kereskedelem Intézet, Marketing Tanszék \\ (University of Debrecen, Faculty of Economics and Business, Institute of Marketing and Commerce, Department of Marketing) \\ H-4032 Debrecen, Böszörményi út 138 . \\ e-mail: kiss.marietta@econ.unideb.hu \\ ${ }^{2}$ Debreceni Egyetem, Gazdaságtudományi Kar, Vezetés és Szervezés Intézet, Emberi Erőforrás Menedzsment Tanszék \\ (University of Debrecen, Faculty of Economics and Business, Institute of Management and Organization Sciences, \\ Department of Human Resource Management) \\ H-4032 Debrecen, Böszörményi út 138.
}

Our study reviews the rapidly growing marketing literature on the organic label effect, and classifies it based on the underlying explanatory principles (theoretical background). Two broad categories of these studies are identified. The first consists of papers based on the image transfer or on the halo effect, and the second is composed of examinations built on signaling models. After reviewing 60 papers we can conclude that although the presence of the organic label effect has already been proven by many examinations in different contexts, its theoretical foundation is predominantly ad hoc: the authors of the reviewed studies do not justify that the choice of the underlying theory is the most fitting to the situation; moreover we could not find any studies comparing the relevance of the alternative explanations.

KuLCSSZAVAK: organikuscímke-hatás, imázstranszfer, halo-hatás, signaling

JELKóD: D82, Q13, L15

\section{BEVEZETÉS - INTRODUCTION}

A biotermékek egyre bővülő piacának (LIANG, 2015) köszönhetően a szakirodalom egyre szélesebb körben foglalkozik az organikus/bio ${ }^{1}$ termékek marketingjével. Ezek közül egyes kutatások arra fókuszálnak, hogy milyen hatással van a „bio” címke a fogyasztókra. Több tanulmány, többféle megközelítésben vizsgálta
KeYwORDS: organic label effect, image transfer, halo effect, signaling 
nosítottuk (részben új csoportosítási szempontot is kialakítva), amelyek alapján a következő kategóriák szerint mutatjuk be a tanulmányokat:

- imázstranszfer és/vagy halo-hatás²,

- jelzési (signaling) modellek.

Természetesen vannak olyan cikkek, amelyek nem egyértelmúen sorolhatóak be e fenti csoportokba, vagy esetleg párhuzamosan mindkét magyarázatra támaszkodnak, ezeket jelen tanulmányban nem szerepeltetjük, mivel célunk éppen a különbségek explicitté tétele. Meg kell jegyezni azt is, hogy a szerzók nem kívánnak ítéletet mondani egyik vagy másik megközelítés értékéről sem, célunk csupán a bemutatás és a kategorizálás.

Tanulmányunk következő részében az organikus élelmiszerek esetén megjelenő imázstranszfer és a halo-hatás irodalmát mutatjuk be együttesen, majd a releváns jelzési modelleket ismertetjük.

\section{IMÁZSTRANSZFER ÉS \\ HALO-HATÁs - IMAgE TRANSFER AND HALO EFFECT}

Az imázstranszfer fogalmát eredetileg termékek jellemzőihez kötődő asszociációk másik termékre történő átvitelére alkalmazták (SCHWEIGER, 1978), de használatát kiterjesztették többek között a származási ország (VERLEGH és STEENKAMP, 1999), a szponzoráció (például CARRILLAT, SOLOMON és D’ASTOUS, 2015) és a termékcímkék hatásának (amelyet alább mutatunk be részletesen) vizsgálatára is. A széleskörü alkalmazás miatt az imázstranszfernek több definíciója is használatban van, ezért jelen tanulmány az organikus címkékre vonatkozóan a következő meghatározást tekinti kiindulópontnak: imázstranszfer alatt azt a jelenséget értjük, amikor az organikus eredet befolyásolja más érzékszervi vagy nem érzékszervi tulajdonságok megítélését azáltal, hogy átviszi (transzferálja) az organikus eredethez kapcsolódó asszociációkat a megjelölt termékekre, azok egyes termékjellemzőire.

$\mathrm{Az}$ imázstranszfer-hatáshoz hasonló a halo-hatás (THORNDIKE, 1920), amely azt a tendenciát írja le, hogy általában egy terméket a benyomások összessége alapján ítélünk meg, ahelyett, hogy az egyes termékattribútumokat vennénk figyelembe, amelyek valójában függetlenek egymástól (LEUTHESSER, KOHLI és HARICH, 1995). Más szóval adott jószág egy tulajdonságának értékelése erőteljesen befolyásolja vagy torzítja ugyanazon entitás egyéb tulajdonságainak észlelését (LEE et al., 2013). Ugyanakkor mivel az imázstranszfer és a halo-hatás az organikus címkével kapcsolatos szakirodalomban gyakran keveredik, illetve esetenként szinonimaként használják azokat, ezért tanulmányunkban a kettőt egy csoportként kezeljük.

$\mathrm{Az}$ organikus termékek pozitív imázsát már számos tanulmány kimutatta (GREBITUS et al., 2007; SCHIFFERSTEIN és OUDE OPHUIS, 1998; HUGHNER et al., 2007; ZANOLI és NASPETTI, 2002), bár néhány kutatás negatív kapcsolatot is talált (többek közt LEE et al., 2013; ROUSSEAU, 2015). A szakirodalom jelentős része egyetért abban, hogy az organikus címkéhez kapcsolódó imázstranszfer kiterjed az egészségesség érzetére, a kalóriatartalomra, illetve olyan érzékelt tulajdonságokra, mint az illat és az íz, továbbá befolyásolja a fizetési hajlandóságot is (SCHIFFERSTEIN és OUDE OPHUIS, 1998; HUGHNER et al., 2007; ZANOLI és NASPETTI, 2002). A következőkben az imázstranszfer e területeit tekintjük át.

HEMMERLING et al. (2013) megjegyzi, hogy az organikus címkék alkalmasak arra, hogy a biotermékek pozitív imázsát továbbítsák a fogyasztók felé. Ezt alátámasztja ANNETT et al. (2008) és TAGBATA és SIRIEIX (2008) kutatása is, melyben a megkérdezettek a vakteszthez képest jobban kedvelték (magasabb élvezeti értékűnek vélték) az organikus terméket, miután megtudták, hogy organikus. Ugyanakkor FILLION és ARAZI (2002) kísérletében a fogyasztók egyforma értékelést adtak organikus és a hagyományos narancslevekre a vaktesztben és az organikus címke ismeretében is.

A halo-hatás szerint a fogyasztók az olyan termékek egyéb tulajdonságait is kedvezőbben ítélik meg, amelyek csupán egy pozitív tulajdonsággal rendelkeznek, még akkor is, ha 
a tulajdonságok alapvetően nem állnak kapcsolatban a pozitívan megítélt tulajdonsággal (SCHULDT és SCHWARZ, 2010), mint például az organikus címke jelenléte és az íz. Ennek megfelel CANAVARI et al. (2009) eredménye, mely szerint az organikus címke általános pozitív imázsa torzított ízérzékeléshez vezet. HEMMERLING et al. (2013) úgy magyarázza ezt a jelenséget, hogy a biotermékeket fogyasztók korábbi pozitív ízélményeiból épült ki a biotermékek csoportjának jelenlegi „érzékszervi imázsa”, amely a biocímkével ellátott termékek számára egyfajta márkázásként szolgál. Emellett az organikus termékek prémium és ínyenc szegmensbe való pozicionálása és a kapcsolódó érzékszervi érzékelésre irányuló marketingtevékenységek (például érzékszervi információ megjelentetése a csomagoláson) is hozzájárulhat ehhez az imázshoz.

$\mathrm{Az}$ organikus élelmiszerek jobb ízének imázsa széles körben - bár nem általánosan - elterjedt hiedelem, és az egyik leglényegesebb vásárlási motiváció a fogyasztók számára (BAUER, HEINRICH és SCHÄFER, 2013; PLAßMANN és HAMM, 2009; HUGHNER et al., 2007, KUHNERT et al., 2003; FILLION és ARAZI, 2002), annak ellenére, hogy empirikusan nem igazolt vaktesztekkel, hogy az organikus termékeknek jobb az ízük, mint a hagyományosaknak (lásd többek között ROUSSEAU, 2015; SCHOLDERER et al., 2004). Néhány tanulmány bemutatta, hogy a fogyasztók nem éreznek különbséget a biotermékek és a hagyományos alternatíváik íze között (TOBIN, MOANE és LARKIN, 2013; JOLLY és NORRIS, 1991), míg mások arra jutottak, hogy az organikus termékek jobb ízűek (lásd többek között ANNETT et al., 2008). FILLION és ARAZI (2002) azt találta, hogy az organikus narancslevet jobb ízünek vélték a fogyasztók, mint a hagyományosat, viszont nem talált különbséget az organikus és a hagyományos tej ízének érzékelése között. LEE et al. (2013) eredményei sem egyértelmúek: míg a joghurtok esetén az organikus, addig kekszek esetén a hagyományos címkével ellátottakat vélték ízletesebbnek a fogyasztók. ROUSSEAU (2015) hasonló eredményre jutott csokoládék esetén: a válaszadók többsége a hagyományos csokoládék ízét preferálta az organikus címkével ellátottakhoz képest.
LEE et al. (2013) ugyanakkor megállapítják, hogy mivel a keksz nem tipikusan egészségesnek vélt élelmiszer (csakúgy, mint a csokoládé), a fogyasztók úgy érzékelhetik, hogy az „egészségesebb” étel nem olyan jó ízü. Ez számos korábbi tanulmánnyal egybevág, melyek bemutatták, hogy a fogyasztók azt a félrevezető, mégis elterjedt nézetet vallják, hogy a legtöbb egészséges étel rossz ízű, és a legtöbb egészségtelen jó ízü (WANSINK, 1994). RAGHUNATHAN, NAYLOR és HOYER (2006) szintén beszámol arról, hogy ez a feltételezés létezik a fogyasztók körében, melyet ők az „egészségtelen = ízletes” intuíciónak neveztek. Ezen intuíció szerint az emberek hajlamosak azt hinni, hogy egy egészségtelen étel eredendően ízletesebb, ami azt is sugallja, hogy az emberek az egészséges termékeket kevésbé ízletesnek észlelnék. Ez az „egészséges = nem ízletes" heurisztika elég erősnek tűnik ahhoz, hogy ne csak a fogyasztói értékítéletet, hanem a fogyasztók aktuális ízélményének élvezeti minőségét is befolyásolja (SCHULDT és HANNAHAN, 2013). SCHULDT és HANNAHAN (2013) azt is megjegyzik, hogy az organikus címke ízre gyakorolt hatása függ a fogyasztóktól: vizsgálatukban a kevésbé környezettudatos fogyasztók értékelése alacsonyabb ízminőséget mutatott, mint a környezettudatosaké.

BRUNSO, FJORD és GRUNERT (2002) szerint, ha a fogyasztóknak az organikus termékek jobb ízére vonatkozóan elvárásaik vannak (melyek talán nem is reálisak), akkor ezen elvárások negatív visszaigazolása egy újabb potenciális akadályt jelent az organikus termékek iránti kereslettel szemben. Ha a fogyasztók felismerik, hogy az organikus termékek íze nem felel meg az elvárásoknak, akkor néhány esetben arra következtethetnek, hogy választani kell - azaz létezik egyfajta trade-off - az íz és az előállítási folyamat között.

Habár nincs egyértelmű bizonyíték arra nézve, hogy az organikus élelmiszerek egészségesebbek, mint a konvencionálisak (TORJUSEN, NYBERG és WANDEL, 1999), a fogyasztók mégis több tanulmány szerint egészségesebbnek érzékelik az organikus címkével ellátottakat (HUGHNER et al., 2007; GRANKVIST és BIEL, 2001; MAGNUSSON et al., 2001; SCHULDT és HANNAHAN, 2013; 
TORJUSEN, NYBERG és WANDEL 1999). A fogyasztók érzékelésében az organikus termelési folyamat nem jelent önálló minőségdimenziót, hanem bonyolult kapcsolatban áll más minőségdimenziókkal, különösen az egészségességgel. Gyakori fogyasztói hiedelem, hogy az organikus előállítási folyamatnak egészségességre vonatkozó konzekvenciái vannak, ezért úgy vélik, hogy a biotermékek egészségesebbek (BRUNSO, FJORD és GRUNERT, 2002).

$\mathrm{Az}$ organikus eredet jelölése kutatások szerint különösen alkalmas arra, hogy kiváltsa az úgynevezett „egészség-halo-hatást” (ANDREWS et al., 1998; CHANDON és WANSINK, 2007; ROE, LEVY és DERBY, 1999), ami ahhoz vezethet, hogy a fogyasztók egészségesnek látják a termékeket azon dimenziók mentén is, amelyekről az organikus jelzó semmit nem állít (például alacsony kalóriatartalmat társítanak hozzá) (ELLIOTT, 2012; SCHULDT és SCHWARZ, 2010). LEE et al. (2013) kóstoltatásos kísérletében a biocímkével ellátott termékekről a fogyasztók úgy vélték, hogy alacsonyabb kalóriatartalmúak, mint a konvencionális élelmiszerek. Ezzel megegyező eredményre jutottak magyar mintán KISS, KONTOR és KUN (2015) is. Hasonlóan ezekhez SCHULDT és SCHWARZ (2010) egy számítógépes vizsgálat keretén belül kimutatták, hogy egy ténylegesen létező élelmiszer, az Oreo keksz (nem létező) organikus verziójának a fogyasztók alacsonyabb kalóriatartalmat tulajdonítottak, mint a hagyományos verziónak. Kutatásuk eredményeként megállapították, hogy az organikus eredetre vonatkozó állítás hatása a kalória megítélésére hangsúlyosabb volt azok között, akik pozitívabb attitűddel rendelkeztek az organikus termeléssel szemben.

A márkaérték irodalma szerint a fogyasztók akkor hajlandóak magasabb árat fizetni, ha nagyobb az érzékelt érték. Így a fogyasztók szempontjából a biocímke hozzáadott értéket ad a márkához, azaz egészségesebbnek, hedonisztikusabbnak, környezetbarátabbnak és biztonságosabbnak érzékelik a címkével ellátott termékeket, mint a hagyományosakat, ezért nő a felárfizetési hajlandóságuk is (BAUER, HEINRICH és SCHÄFER, 2013). SCHOLDERER et al. (2004), GARCIAYI (2015), NAPOLITANO et al. (2008), LEE et al. (2013), VAN LOO et al. (2011), TAGBATA és SIRIEIX (2008), valamint MILLOCK et al. (2002) kimutatták, hogy az organikus címkével ellátott termékek esetén a fizetési hajlandóság (WTP) magasabb, mint a konvencionális termékek esetén, míg ugyanez TAGBATA és SIRIEIX (2008), illetve SCHOLDERER et al. (2004) kutatásában a vakteszt során fordított eredménnyel járt. Mindemellett megállapították, hogy (tej esetében) a fogyasztók gyakran hajlamosak túlbecsülni a tényleges fizetési hajlandóságukat; továbbá létezik egy széles fogyasztói réteg, amely hajlandó lenne a konvencionális termékekhez képest többet fizetni az organikus termékekért, de annyit nem, amennyi annak tényleges piaci ára (MILLOCK et al., 2002). ROUSSEAU (2015) az előzőekkel ellentétben azt mutatta ki, hogy a biocsokoládék iránti fizetési hajlandóság legalább néhány esetben kisebb, mint a hagyományos csokoládék iránti.

$\mathrm{Az}$ organikus árukkal szembeni keresletet korlátozza azok magas, prémium kategóriás ára. GLASER és THOMPSON (1998), valamint WIER, HANSEN és SMED (2001) a bio- és a nembio-élelmiszerek közötti helyettesíthetőséget modellezték. Ugyanazt a sémát azonosította mindkét kutatás: az organikus termékek iránti keresletet árrugalmasabbnak találták, mint a konvencionális termékek keresletét. Ezekkel az eredményekkel ellentétben JÖRGENSEN (2001, idézi MILLOCK et al., 2002), aki különböző müzlik és kávék keresletét becsülte meg, viszonylag alacsony árrugalmasságot állapított meg a biotermékek esetén. 


\section{A JELZÉSI MODELLEK -} SigNALING MODELS

Az irodalom általunk második csoportba sorolt része az organikus címkék hatását a közgazdaságtan által jelzésnek (signaling) nevezett jelenségként értelmezi. Cikkünk nem kívánja ismertetni a teljes jelzési irodalmat, csupán a számunkra fontos - az organikuscímke-hatáshoz kapcsolódó - leglényegesebb elemeit mutatjuk be.

Maga a jelzési irodalom SPENCE (1973) cikkével lett a közgazdasági irodalom része, de az elmélethez vezető út talán legfontosabb mérföldköve AKERLOF (1970) tragacspiac-modellje, mely azt mutatta be, hogyan vezethet az információs aszimmetria jelenléte kontraszelekcióhoz (a jó minőségű termékek piacról való kiszorulásához és ez által akár a piacok összeomlásához is). AKERLOF (1970) nyomán azt a piaci szituációt nevezi a közgazdaságtan információs aszimmetriának, amelyben a piac egyes szereplői (jellemzően az eladók) több információval rendelkeznek a csere tárgyáról, mint más szereplők (jellemzően a vevők). Az organikus termékek esetében nyilvánvalóan ilyen jelenséggel állunk szemben, hiszen az élelmiszerről a vevő nem tudja költségmentesen és gyorsan megállapítani, hogy például mennyire egészséges. Hivatkozott cikkének végén már AKERLOF (1970) is említi, hogy léteznek a jó minőségű termékek eladói által használható, információs aszimmetria ellen ható, a vevőt a termék minőségről valamilyen formában tájékoztató eszközök (intézmények): garanciák, márkaépítés, múködési engedélyek és végül a különböző bizonyítványok, tanúsítványok. Utóbbiak közé tartozik természetesen az organikus termelés és eredet valamilyen szervezet általi igazolása is.

SPENCE (1973) cikkére volt azonban szükség, hogy ezek múködési elvét is megértsük. Ez alapján a jelzés mechanizmusának lényege röviden úgy foglalható össze (leszúkítve az általunk vizsgált problémára), hogy

- ha nem mérhető a termék minősége (például egészségesség) közvetlenül, vagy csak túl költségesen, viszont

- létezik egy olyan intézmény (mint az elismert minősítő intézetek), amelyikről a vevők és az eladók is tudják, hogy megfelelő biztonsággal képes mérni a termék valamely másik jellemzőjét (például az organikus termelés szabályainak betartása) és erról hiteles tanúsítványt állíthat ki, amely

- jó előre jelzője (proxyja) a vevő által tudni kívánt jellemzőnek (például egészségesség), mert

- csak a jó minőségü (egészséges) termékek eladóinak éri meg ebbe a tanúsítványba beruházni (a rossz minőséget termelőknek ez túl költséges a várható haszonhoz képest), továbbá

- ez a tanúsítvány relatíve olcsón elérhető a vevő számára, akkor

- a jó minőségű termékek termelői be fognak ebbe ruházni (azaz az egészséges termékeket termelők hiteles organikus címkékkel látják el termékeiket), a rossz minőséget előállítók viszont nem, továbbá

- a vevők a magasabb minőség igazolását (a címkét) a magasabb áron keresztül meg is fizetik a piacon, és

- ezzel beáll az úgynevezett szétválasztó (separating) egyensúly (amelyben a címke valóban elkülöníti egymástól az organikus és nem organikus termelőket).

Természetesen előfordulhat, hogy nem jutunk el a szeparáló egyensúlyhoz, mert a jó és a rossz minőséget árulóknak egyaránt megéri vagy egyaránt nem éri meg a jelzésbe beruházni (ez az elegyítő, angolul „pooling” egyensúly). A valódi piacokon tipikusan a szeparáló egyensúly létrehozása lenne a címkézés célja, hiszen így a jobb minőséget (például az átlagosnál egészségesebb élelmiszereket) előállítóknak megéri ezt a magasabb minőséget termelni, a fogyasztók közül pedig a jó minőséget igénylők is megbízható útmutatást kapnak a címkéktől.

Fontos a fentiekból azt az implicit feltételt is kiemelni, hogy ha az organikus címke a termékek megtapasztalt jellemzőit (például ízét vagy illatát) javítja, akkor nem jelzéssel állunk szemben, hiszen annak éppen az a lényege, hogy valamely közvetlenül nem vagy csak nagyon drágán megfigyelhető jellemzőt helyettesít másik, olcsóbb vagy hozzáférhetőbb információval.

$\mathrm{Az}$ információs aszimmetria modelljeit - köztük a jelzési elméletet is - már korán használni kezdték a marketing különböző kérdésköreinek elemzésére. A legismertebb 
talán a termékek megismerhetőség szerinti osztályozása és az erre épülő, reklámozási tevékenységre való alkalmazás. NELSON (1970) megkülönböztette a keresési (search goods) és a tapasztalati (experience goods) termékeket, melyek közül az utóbbiak lettek az információs aszimmetria tipikus alanyai, mert a vásárló csak úgy derítheti ki minőségüket, ha megvásárolja, vagy akár csak akkor, ha el is fogyasztja (megtapasztalja) óket (szemben az előbbi jószágcsoporttal, amely már a vásárlás előtt kellően megismerhető). Ilyenek például a konzervek: amíg nem vesszük meg őket, addig nem tekinthetünk beléjük. DARBY és KARNI (1973) egy harmadik árutípust is bevezetett az előbbi kettő mellé: a bizalmi termékeket (credence goods), melyek lényeges tulajdonságai még a fogyasztás során/után sem derülnek ki. Az organikus termékek bizonyos tulajdonságai tipikusan ebbe az utóbbi csoportba sorolhatóak (például sem a termelés módja, sem a termék egészségessége nem ismerhető meg a fogyasztáson keresztül).

Később NELSON (1974) a jelzési mechanizmust is azonosította a reklámozási kiadásokban. A termékekről általában is megéri információt közölni, ha azok jók, hiszen a fogyasztó ezt a vásárlás, majd az újravásárlások során megtéríti. Tapasztalati és különösen bizalmi javakról viszont definíció szerint nem közölhető hitelesen információ. Ilyen esetben is megéri azonban reklámozni, méghozzá annak jelzési értéke miatt: a fogyasztók tudják, hogy csak azoknak térülnek meg a reklámköltségek, akik számíthatnak a termékek újravásárlására is, és alacsony minőségű termék esetén ez nem következik be. Vagyis a fogyasztók tudják, hogy a reklámra többet költők valószínúleg jobb terméket árulnak. Ezt a vonalat vitte tovább többek között MILGROM és ROBERTS (1986), HERTZENDORF (1993), valamint LINNEMER (2008) a disszipatív reklámok elemzésével (olyan hirdetések, melyek nem ösztönöznek közvetlenül fogyasztásra, de magas költségük nyilvánvaló a fogyasztó számára).

Bár az információk megosztására fordított kiadások közé (akár disszipatívak, akár fogyasztásra ösztönzőek) könnyen besorolhatjuk az organikus eredet igazolását is, és így a felsorolt szerzők munkái ennek értelmezésére is felhasználhatóak, mégis a jelzési modelleknek direkt módon az organikus termékek piacára való tudatos alkalmazása még kevéssé elterjedt a szakirodalomban. Éppen ezért itt néhány olyan cikket is bemutatunk, melyek nem kifejezetten erre a címketípusra vonatkoznak, de tanulságaik hasznosak lehetnek a biocímkék esetében is.

MCCLUSKEY (2000) játékelméleti módszertanra építve mutatja be - fóként az organikus termékek példáján -, hogy a bizalmi javaknál csak akkor létezhet piaca a jó minőségü, illetve valóban az adott, nem megfigyelhető jellemzővel bíró (például valóban organikus módon előállított) javaknak, ha (1) létezik hiteles külső ellenőrző szervezet, mely jelzi ezt a fogyasztó számára, és (2) a vásárlás ismétlődő. Ellenkező esetben ugyanis az információs aszimmetria erkölcsi kockázatot (moral hazard) teremt, vagyis az eladók hamisíthatják a címkéket; például egy nem organikus termelő organikus címkéket szerepeltethet a termékén, a „lebukás” veszélye nélkül, hiszen a bizalmi javakról a vevő később sem tudja kideríteni azok valódi tulajdonságait. A játék során az ismétlődés biztosítja, hogy jelentős legyen az esélye annak, hogy valamelyik ellenőrzés során (amit az igazolást kiállító szervezet végez) kiderülhessen, ha a címke használója csalt. A gyakori ellenőrzés praktikus szempontból tapasztalati jószággá változtatja a bizalmi jószágot, hiszen a vásárlást követően kiderül a termék valódi minősége. Kiemeli a szerző azt is, hogy egységes - nemzeti vagy nemzetközi - standardokra van szükség, ezek nélkül ugyanis maga az organikusság vagy más jellemző jelentése és így a címkén szereplő jelzés sem lesz egyértelmű a fogyasztóknak. A cikk megállapításai nem csak a bio, de más bizalmi jellemzőkkel bíró javak esetében alkalmazott címkékre is érvényesek.

MARIOJOULS és WESSELLS (2002) a francia tengeri eredetü élelmiszerek (seafood products) piacán vizsgálta több hivatalos tanúsító címke használatát és hatásait. Ők a címkék hatását elsősorban azok versenyt befolyásoló szerepében látják (szegmentálják a piacot), legyen szó akár regionális eredetet, termelési módot, csúcsminőséget vagy akár speciális sztenderdeknek való megfelelést igazoló jelzésekról. A cikk nem explicit módon, de azt a kérdést feszegeti, müködhetnek-e, illetve hogyan müködhetnek a termékcímkék hatékony jelzés- 
ként (amelyek létrehozzák a kívánatos szeparáló egyensúlyt). Milyen karakterisztikákat kellene címkékkel tanúsítani, hogy azt a fogyasztók a magasabb minőség jelzéseként értékeljék és hajlandóak legyenek érte árprémiummal fizetni? Felveti a cikk továbbá azt a kérdést is, hogy vezethetnek-e a hatósági címkézési programok társadalmi megtérüléshez a cserék száma és ezáltal a termelés növekedésén, illetve az ellátási láncok optimalizálásán keresztül.

WESSELLS (2002) összevontan vizsgálta a fogyasztókat informáló címkefajták (az organikus mellett például a környezetbarát és a hazai termelés tanúsítványainak) hatását a tengeri eredetű élelmiszerekre vonatkozóan. Saját empirikus vizsgálatot a tanulmány nem tartalmaz, hanem szakirodalmi eredményekre épít. Legfóbb megállapítása, hogy a tengeri élelmiszerek piacán is van kereslet a címkékkel jelezhető, bizalmi tulajdonságokra vonatkozó információkra, de a szerző szerint további vizsgálatot igényel, hogy ezek pontosan milyen információk legyenek (vagyis hogy mely címkékbe érdemes beruházni a termelőknek vagy a hatóságoknak ezen a konkrét piacon).

Mind a gyakorlati marketing, mind az empirikus kutatások szempontjából fontos megállapítás, hogy az emberek jelzésbefogadó kapacitása korlátozott, ezért egy jelzésnek el kell érnie a kellő intenzitást ahhoz, hogy kimutatható legyen a hatása (FALKINGER, 2008). WARTELLA et al. (2011) az élelmiszercímkék esetében egyrészt arra hívják fel a figyelmet, hogy a jelzési hatás egy valós, komplex vásárlási helyzetben csak akkor érvényesülhet, ha a címke kellően magára tudja vonni a figyelmet (méreténél, színénél, elhelyezésénél és egyszerü értelmezhetőségénél fogva). Másrészt arra is, hogy ha több címke is jelen van a termék csomagolásán, akkor ezek egymás hatására is befolyással vannak, akár semlegesíthetik is egymást. Megjegyzik továbbá, hogy különböző fogyasztói csoportokra másképp hathat egyegy címke, illetve lehetnek a címkéknek nemkívánatos hatásai is (például az egészségességhez a rosszabb ízt társíthatják). Az organikus címkék jelző hatását a márkanév jelenléte mellett (kétjelzéses modell) vizsgálta LARCENEUX, BENOIT-MOREAU és RENAUDIN (2012) vásárlási szituációban. Azt találták, hogy a két jelzés valóban hat egymásra, de helyzettől függően változhat az organikus címke márkanév jelenlétében mutatott hatásának erőssége. Erős márkaérték mellett az organikus címke hatása tipikusan gyenge.

BANSAL, CHAKRAVARTY és RAMASWAMI (2013) a génmódosítást (GMO) jelző címkék jelzési hatását vizsgálták a fogyasztók fizetési hajlandóságára kekszek esetében, méghozzá úgy, hogy megpróbálták (kevés sikerrel) ezt elkülöníteni az általuk információs hatásnak nevezett azon jelenségtől, hogy magának a biztos tudásnak is van pszichológiai többletértéke a bizonytalan tudáshoz képest. Vagyis egy címke hatása eredhet abból is, hogy biztossá teszi az információt és abból is, hogy jelez valamilyen egyébként nem észlelhető terméktulajdonságot. Kóstoltatásos kísérletüket formális modellel alapozták meg, és a GMO címkék fogyasztási hajlandóságra gyakorolt negatív hatását azonosították, illetve megállapították azt is, hogy az információs hatás dominálta a jelzésit. Az organikus címkék esetében nyilván ellentétes hatásra számíthatunk, hiszen a GMO általában negatív, az organikusság általában pozitív megítélést élvez. COSTANIGRO és LUSK (2014) szintén a GMO címkéket vizsgálták, de ők a kötelező címkékre szorították vizsgálatukat, mellyel mérsékelt jelzési hatást mutattak ki.

ATKINSON és ROSENTHAL (2014) az ökocímkék kialakítását, információtartalmát vizsgálták empirikusan jelzési szempontból. Azt találták, hogy bár egyenként kicsi, de szignifikáns hatásuk van a következőknek: menynyire pontos és lényeges a közölt információ, ki a címke kiállítója (a hatósági eredet nagyobb bizalmat eredményezett, mint a magánszervezeti). Mind a címke tartalma, mind pedig az, hogy ki állította ki, betöltheti a jelzés szerepét, de eltérő szituációkban eltérő intenzitással. Általában véve a címkeinformációk specifikussága a hatásosabb jelzés.

Összefoglalóan megállapíthatjuk, hogy a jelzési elmélet az organikus címkék hatásának vizsgálatában kevés tanulmányban jelenik meg. Mint az a fenti áttekintésból is látható, előfordul, hogy az információs aszimmetriáig eljutnak az adott cikk szerzői, de vagy annak elméleti eredményeit sem használják fel, vagy nem lépnek tovább addig, hogy a címkéket beazonosítsák jelzésként (így az ennek elemzé- 
sében elért eredményeket sem használják fel). A kevés pozitív kivétel azonban rámutat arra, hogy a jelzési modellek eredményesen használhatóak az organikuscímke-hatás és részjelenségeinek vizsgálatához.

\section{KöVETKEZTETÉSEK - CONCLUSIONS}

Áttekintve az organikuscímke-hatás releváns marketing irodalmát megállapíthatjuk, hogy az imázstranszfer és a halo-hatás teszi ki az organikuscímke-hatást magyarázó publikációk döntő többségét, míg a jelzési irodalom mennyiségét tekintve (egyelőre) marginális. Ennek egyik oka lehet a szerzők szerint, hogy a jelzési modellek alkalmazása egyszerre igényli a marketing ismereteket és a közgazdaságtan módszereiben való jártasságot, ami mind a lehetséges szerzők számát korlátozhatja, mind a befogadó folyóiratokét. Ugyanakkor megállapíthatjuk, hogy a jelzési irodalom területén is születtek jelentős eredmények, tehát érdemes lenne ezt a kutatási vonalat a jövőben erősíteni.

Feltűnő továbbá, hogy a feldolgozott tanulmányok egy részében az imázstranszfer és a halo-hatás koncepciói keverednek, több esetben szinonimaként használják azokat, holott jól elkülöníthetők egymástól, definícióik a szakirodalomban ismertek. Ez megnehezítheti a témában született eredmények értékelését és összevetését.

Megállapítható továbbá, hogy maga az organikuscímke-hatás jelensége számos alkalommal, számos termékfajta és terméktulajdonság esetében megerősítést nyert; létezéséhez mára kétség nem fér. Ami továbbra sem tisztázott kellő mértékben, és amire cikkünkben mi is felhívtuk a figyelmet, az a jelenség vizsgálatának és magyarázatának elméleti kerete. A bemutatott három magyarázóelv (transzferhatás, halo-hatás, jelzés) külön-külön és egymás mellett is megállhatja a helyét, azonban a szerzők hiányolják a lehetséges magyarázatok alkalmazhatóságának vizsgálatát a szakirodalomból. Mint minden társadalmi-gazdasági jelenség esetében, nyilván az organikus címkék hatásainak esetében is igaz, hogy többféle mo- dellel leírhatóak, elemezhetőek, de a konkrét szituációk paramétereitől függően ezek közül egyiknek vagy másiknak nagyobb a magyarázó ereje. Hasznos jövőbeli kutatási irány lehetne tehát az egyes modellek különböző feltételek közötti alkalmazhatóságának vizsgálata, esetleg kombinált modellek kidolgozása, melyek a komplex, valós szituációkat sikeresebben közelíthetnék meg.

\section{IRODALOMJEGYZÉK - REFERENCES}

Akerlof, G. A.: The Market for "Lemons": Qualitative Uncertainty and the Market Mechanism. In: The Quarterly Journal of Economics. 1970. 84 (3) 488-500.

Andrews, J. C. - Netemeyer, R. G. Burton, S.: Consumer generalization of nutrient content claims in advertising. In: Journal of Marketing. 1998. 62 (4) 62-75.

Annett L. E. - Muralidharan, V. - Boxall, P. C. - Cash, S. B. - Wismer, W. V.: Influence of Health and Environmental Information on Hedonic Evaluation of Organic and Conventional Bread. In: Journal of Food Science. 2008. 73 (4) 5057.

Atkinson, L. - Rosenthal, S.: Signaling the Green Sell: The Influence of Eco-Label Source, Argument Specificity, and Product Involvement on Consumer Trust. In: Journal of Advertising. 2014. 43 (1) 33-45.

Bansal, S. - Chakravarty, S. Ramaswami, B.: The Informational and Signaling Impacts of Labels: Experimental Evidence from India on GM Foods. In: Environment and Development Economics. 2013. 18 (6) 701-722.

Bauer, H. H. - Heinrich, D. - Schäfer, D. B.: The Effects of Organic Labels on Global, Local and Private Brands. More Hype than Substance? In: Journal of Business Research. 2013. 66 (8) 10351043.

Brunso, K. - Fjord, T. A. - Grunert, K. G.: Consumer Food Choice and Quality Perception. Working Paper No. 77. 2002. The Aarhus School of Business, Mapp, Denmark 
Canavari, M. - Asioli, D. - Bendini, A. - Cantore, N. - Gallina Toschi, T. - Spiller, A. - Obermowe, T. - Buchecker, K. - Lohmann, M.: Summary Report on Sensory-related Socioeconomic and Sensory Science Literature about Organic Food Products. Deliverable No. 1.2 of EU Project Ecropolis. 2009. URL: http://orgprints.org/17208/2/ deliverable_1_2_sensory_literature.pdf (Letöltés dátuma: 2015. ápr. 5.)

Carrillat, F. A. - Solomon, P. J. d'Astous, A.: Brand Stereotyping and Image Transfer in Concurrent Sponsorships. In: Journal of Advertising. 2015. 44 (4) 300-314.

Chandon, P. - Wansink, B.: The Biasing Health Halos of Fast-food Restaurant Health claims. Lower Calorie Estimates and Higher Side-dish Consumption Intentions. In: Journal of Consumer Research. 2007. 34 (3) 301-314.

Costanigro, M. - Lusk, J. L.: The Signaling Effect of Mandatory Labels on Genetically Engineered Food. In: Food Policy. 2014. 49 (1) 259-267.

Darby, M. - Karni, E.: Free Competition and the Optimal Amount of Fraud. In: Journal of Law and Economics. 1973. 16 (1) 67-88.

Elliott, C.: Packaging Health. Examining "Better-for-you" Foods Targeted at Children. In: Canadian Public Policy. 2012. 38 (2) 265-281.

Falkinger, J.: Limited Attention as a Scarce Resource in Information-rich Economies. In: The Economic Journal. 2008. 118 (532) 1596-1620.

Fillion, L. - Arazi, S.: Does Organic Food Taste Better? A Claim Substantiation Approach. In: Nutrition and Food Science. 2002. 32 (4) 153-157.

Garcia-Yi, J.: Willingness to Pay for Organic and Fairtrade Certified Yellow Chili Peppers. In: British Food Journal. 2015. 117 (2) 929-942.

Glaser, L. K. - Thompson, G. D.: Demand for Organic and Conventional Frozen Vegetables. American Agricultural Economics Association Annual Meeting. Nashville, Tennessee, 8-11. Aug. 1998.
Grankvist, G. - Biel, A.: The Importance of Beliefs and Purchase Criteria in the Choice of Eco-labeled Food Products. In: Journal of Environmental Psychology. 2001. 21 (4) 405-410.

Grebitus, C. - Yue, C. - Bruhn, M. Jensen H. H.: What Affects Consumption Patterns of Organic and Conventional Products? American Agricultural Economics Association Annual Meeting. Portland, US, 29 July - 1 Aug. 2007.

Hemmerling, S. - Obermowe, T. Canavari, M. - Sidali, K. L. - Stolz, H. - Spiller, A.: Organic Food Labels as a Signal of Sensory Quality - Insights from a Cross-cultural Consumer Survey. In: Organic Agriculture. 2013. 3 (1) 57-69.

Hertzendorf, M. N.: I'm Not a High-Quality Firm - But I Play One on TV. In: The RAND Journal of Economics. 1993. 24 (2) 236-247.

Hughner, R. E. S. - McDonagh, P. - Prothero, A. - Schultz, C. J. Stanton, J.: Who are Organic Food Consumers? A Compilation and Review of Why People Purchase Organic Food. In: Journal of Consumer Behaviour. 2007. 6 (2-3) 94-110.

Janssen, M. - Hamm, U.: Product Labelling in the Market for Organic Food: Consumer Preferences and Willingness-to-pay for Different Organic Certification Logos. In: Food Quality and Preference. 2012. 25 (1) 9-22.

Jolly, D. A. - Norris, K.: Marketing Prospects for Organic and Pesticidefree Produce. In: American Journal of Alternative Agriculture. 1991. 6 (4) 174179.

Kiss, M. - Kontor, E. - Kun, A. I.: The Effect of 'Organic' Labels on Consumer Perception of Chocolates. In: The Annals of the University of Oradea. Economic Sciences. 2015. 23 (1) 448-457.

Kuhnert, H. - Feindt, P. H. - Wragge, S. - Beusmann, V.: Nachfrage nach ÖkoLebensmitteln: Veränderung durch BSE? In: Ökologie \& Landbau. Jahrbuch ÖkoLandbau. 2003. 125 (1) 29-32. 
Larceneux, F. - Benoit-Moreau, F. Renaudin, V.: Why Might Organic Labels Fail to Influence Consumer Choices? Marginal Labelling and Brand Equity Effects. In: Journal of Consumer Policy. 2012. 35 (1) 85-104.

Lee, W.-c. J. - Shimizu, M. - Kniffin, K. M. - Wansink, B.: You Taste what You See: Do Organic Labels Bias Taste Perceptions? In: Food Quality and Preference. 2013. 29 (1) 33-39.

Leuthesser, L. - Kohli, C. S. - Harich, K. R.: Brand Equity: The Halo Effect Measure. In: European Journal of Marketing. 1995. 29 (4) 57-66.

Liang, R. D.: Predicting Intentions to Purchase Organic Food: The Moderating Effects of Organic Food Prices. In: British Food Journal. 2016. 118 (1) 183-199.

Linnemer, L.: Dissipative Advertising Signals Quality Even Without Repeat Purchases. In: CESifo Working Paper Series No. 2310. 1. May 2008.

Magnusson, M. K. - Arvola, A. - Koivisto Hursti, U.-K. - Åberg, L. - Sjödén, P.-O.: Attitudes Towards Organic Foods Among Swedish Consumers. In: British Food Journal. 2001. 103 (3) 209-226.

Mariojouls, C. - Wessells, C. R.: Certification and Quality Signals in the Aquaculture Sector in France. In: Marine Resource Economics. 2002. 17 (3) 175-180.

McCluskey, J. J.: A Game Theoretic Approach to Organic Foods: An Analysis of Asymmetric Information and Policy. In: Agricultural and Resource Economics Review. 2000. 29 (1) 1-9.

Milgrom, P. - Roberts, J.: Price and Advertising Signal of Product Quality. In: Journal of Political Economy. 1986. 94 (4) 796-821.

Millock, K. - Hansen, L. G. - Wier, M. M. - Andersen, L. M.: Willingness to Pay for Organic Foods: A Comparison Between Survey Data and Panel Data from Denmark. Second World Congress of Environmental and Resource Economists. Monterey, USA, 24-27. June 2002. URL: http://orgprints.org/oooo1754 (Letöltés dátuma: 2015. ápr. 21.)
Napolitano, F. - Pacelli, C. - Girolami, A. - Braghieri, A.: Effect of Information About Animal Welfare on Consumer Willingness to Pay for Yogurt. In: Journal of Dairy Science. 2008. 91 (3) 910-917.

Nelson, P.: Information and Consumer Behavior. In: Journal of Political Economy. 1970. 78 (2) 311-329.

Nelson, P.: Advertising as Information. In: Journal of Political Economy. 1974. 82 (4) 729-754.

Plaßmann, S. - Hamm, U.: Kaufbarriere Preis? Analyse von Zahlungsbereitschaft und Kaufverhalten bei Öko-Lebensmitteln. Final report of BÖL-project O6OE119. 2009. URL: http://orgprints. org/15745/1/15745-o6OE119-uni_kasselhamm-2009-kaufbarriere_preis.pdf (Letöltés dátuma: 2015. ápr. 5.)

Raghunathan, R. - Naylor, R. W. - Hoyer, W. D.: The Unhealthy = Tasty Intuition and its Effects on Taste Inferences, Enjoyment, and Choice of Food Products. In: Journal of Marketing. 2006. 70 (4) 170-184.

Roe, B. - Levy, A. S. - Derby, B. M.: The Impact of Health Claims on Consumer Search and Product Evaluation Outcomes. Results from FDA Experimental Data. In: Journal of Public Policy \& Marketing. 1999. 18 (1) 89-105.

Rousseau, S.: The Role of Organic and Fair Trade Labels When Choosing Chocolate. In: Food Quality and Preference. 2015. 44 (Sept.) 92-100.

Schifferstein, H. N. J. - Oude Ophuis, P. A. M.: Health-related Determinants of Organic Food Consumption in The Netherlands. In: Food Quality and Preference. 1998. 9 (3) 119-133.

Scholderer, J. - Nielsen, N. A. - Bredahl, L. - Claudi-Magnussen, C. - Lindahl, G.: Organic Pork: Consumer Quality Perceptions. Project paper no 02/04. 2004. URL: http://pure.au.dk/portal/ files/32304683/ppo204.pdf (Letöltés dátuma: 2015. ápr. 19.) 
Schuldt, J. - Hannahan, M.: When Good Deeds Leave a Bad Taste: Negative Inferences from Ethical Food Claims. In: Appetite. 2013. 62 (3) 76-83.

Schuldt, J. P. - Schwarz, N.: The 'Organic' Path to Obesity? Organic Claims Influence Calorie Judgements and Exercise Recommendations. In: Judgement and Decision Making. 2010. 5 (3) 144-150.

Schweiger, G.: Transferring Brand Images. A New Strategy to Increase Advertising Effectiveness; An Empirical Study. In: Marketing piackutatás. 1978. 12 (4) 501504.

Spence, M. A.: Job Market Signaling. In: The Quarterly Journal of Economics. 1973. 87 (3) $355-374$.

Tagbata, D. - Sirieix, L.: Measuring Consumers' Willingness to Pay for Organic and Fair Trade Products. In: International Journal of Consumer Studies. 2008. 32 (5) 479-490.

Thorndike, E. L.: A Constant Error in Psychological Ratings. In: Journal of Applied Psychology. 1920. 4 (1) 469-477.

Tobin, R. - Moane, S. - Larkin, T.: Sensory Evaluation of Organic and Conventional Fruits and Vegetables Available to Irish Consumers. In: International Journal of Food Science and Technology. 2013. 48 (1) 157-162.

Torjusen, H. - Nyberg, A. - Wandel, M.: Organic Food: Consumers' Perceptions and Dietary Choices. SIFO-Report No. 5. 1999. Oslo, Norway.
Van Loo, E. J. - Caputo, V. - Nayga Jr. R. M. - Meullenet, J.-F. - Ricke, S. C.: Consumers' Willingness to Pay for Organic Chicken Breast: Evidence from Choice Experiment. In: Food Quality and Preference. 2011. 22 (7) 603-613.

Verlegh, P. W. J. - Steenkamp, J. B. E. M.: A review and metaanalysis of countryof-origin research. In: Journal of Economic Psychology. 1999. 20 (5) 521-546.

Wansinck, B.: Antecedents and mediators of eating bouts. In: Family and Consumer Sciences Research Journal. 1994. 23 (2) 166-182.

Wartella, E. A. - Lichtenstein, A. H. - Yaktine, A. - Nathan, R.: Frontof-Package Nutrition Rating Systems and Symbols: Promoting Healthier Choices. The National Academies Press, Washington DC, 2011.

Wessells, C. R.: The Economics of Information: Markets for Seafood Attributes. In: Marine Resource Economics. 2002. 17 (2) 153-162.

Wier, M. - Hansen, L. G. - Smed, S.: Explaining Demand for Organic Foods. 11th Annual EAERE Conference. Southampton, UK, 28-30. June 2001.

Zanoli, R. - Naspetti, S.: Consumer Motivations in the Purchase of Organic Food: A Means-end Approach. In: British Food Journal. 2002. 104 (8) 643-653.

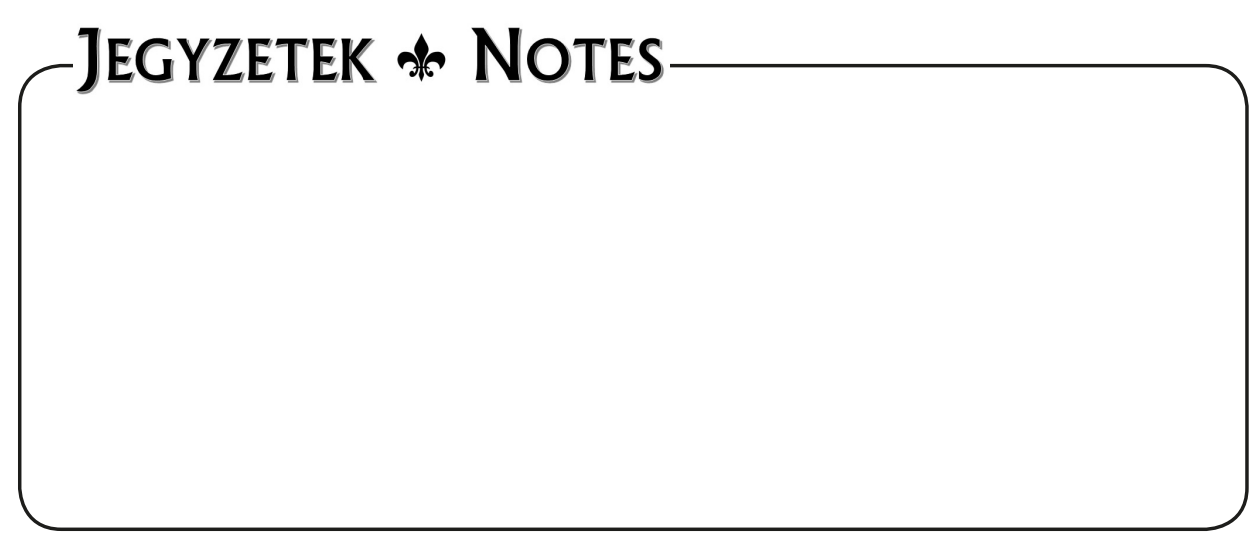


JEGYZETEK $\nRightarrow$ NOTES 